JOMOPS

JOURNAL OF MODERNISM AND POSTMODERNISM STUDIES
Submitted: 24.05.2021 - Accepted: 06.06.2021

Year: July 2021 - Volume: 2 - Issue: 1

DOI: https://doi.org/10.47333/modernizm.2021171852

\title{
DEHUMANIZATION IN SARAH KANE'S POSTMODERN PLAYS
}

\section{SARAH KANE'IN POSTMODERN OYUNLARINDA GAYRI-INSANILEŞTIRME}

\section{Gül KURTULUŞ ${ }^{1}$}

\begin{abstract}
Postmodernism explores society's perspective on stereotypes and ways in which cultural aspects evolve in a globalized world. It focuses on human experience in different forms by taking its motives from historical and societal issues. Postmodernism in drama is based on postmodern philosophy which originated in Europe in the twentieth century. Postmodern theatre, also known as the new theatre, is a reaction against modernist drama. It makes the audience question and evaluate the differences between reality and art. It dwells on the idea that there is no ultimate truth. Plays written in this mode of drama involve images and allusions, and the audience plays an important role, involving in the performance. Moreover, postmodernist drama is innovative in terms of its technique and in defying social conventions. This paper aims to discuss Sarah Kane's plays Blasted Phaedra's Love, Crave, and 4.48 Psychosis as postmodern plays in relation to dehumanization employed as a recurrent theme in the plays. Violence, rapture, alienation, exploitation, and frustration are some of the themes Sarah Kane explores in the above-mentioned plays. This paper argues that Kane considers theatre an instrument to exhibit the ugly images of life. Kane's plays portray hideousness of life in tandem with the use of postmodern theatrical elements.
\end{abstract}

Keywords: Postmodern Theatre, Sarah Kane, Dehumanization, Violence, Love, Death.
Öz

Postmodernizm küresel dünyada toplumun klişelerle ve kültürel olaylarla ilgili bakış açısındaki değişimi ve dönüşümü yakından izler ve keşfeder. İtici gücünü tarihi ve toplumsal olaylardan alan postmodernizm insanın deneyimlediği olayları farklı şekillerde ele alır. Tiyatroda postmodernizm yirminci yüzyılda Avrupa'da ortaya çıkan postmodern felsefeye dayanır. Postmodern tiyatro yeni tiyatro olarak da tanımlanır ve modernist tiyatroya bir tepki olarak doğar. Seyirciye gerçeklik ve sanat arasındaki farklılıkları sorgulatan ve düşündüren bir tiyatro akımı olan postmodern tiyatro, mutlak gerçeğin olmadığını savunur. Bu tarzda yazılan tiyatro oyunları imgelerden ve imlemelerden oluşur. Seyirci performansa katılarak önemli bir rol üstlenir. Öte yandan, postmodern tiyatro kullanılan teknikler açısından da son derece yenilikçidir ve toplumsal geleneklere ve yerleşik düzene meydan okur. Bu çalışmanın amacı Sarah Kane'nin Blasted, Phaedra's Love, Crave ve 4.48 Psychosis oyunlarını postmodern oyunlar olarak ele almak ve oyunlarda tekrar tekrar vurgulanan gayri-insanileştirme temasını incelemektir. Zorbalık, insanlıktan çıkma, kendinden geçme ve kendini kaybetme, yabancılaşma, istismar ve hayal kırıklığı yazarın yukarıda belirtilen eserlerinde ele aldığı temalardandır. Bu çalışmada savunulan görüş, Kane'nin tiyatro sahnesini yaşamın çirkin görüntülerini sergilediği bir mecra olarak gördüğüdür. Kane'nin oyunları postmodern tiyatronun ögelerini kullanarak hayatın çirkinliklerini resmeder.

Anahtar Kelimeler: Postmodern Tiyatro, Sarah Kane, Gayri-insanileştirme, Şiddet, Aşk, Ölüm.

\footnotetext{
${ }^{1}$ Dr., English Language and Literature, Bilkent University, kurtulus@bilkent.edu.tr, https://orcid.org/00000001-8743-6736.
} 


\section{Introduction}

Sarah Kane's plays are contradicting the qualities of the modernist theatre and they represent theatre of violence and In-Yer-Face drama, questioning moral norms, which is primarily dehumanization of the characters. As a distinctive trend in British theatre history, the theatre of violence appears as an anomalous mode among other forms of drama since it presents a "disruptive brutality" on stage (Jordan and Weitz 263). The theatre of the absurd, epic theatre, and the theatre of cruelty employ elements that form the firm ground of postmodern theatre, sharing similar concerns of meaninglessness, futility, and helplessness of human existence. Samuel Beckett and Bertolt Brecht pioneer in establishing a strong bond between modernism and postmodernism. Sarah Kane, one of the leading female playwrights of the 90s with her controversial plays, carries the mentioned disturbingly and uncomfortably presented brutal and wild themes onto the stage in a unique way. As a practitioner of novelty in theatre, Kane utilizes satirical themes and violent imageries to raise ethical questions. The practice of this mode of drama offers a unique experience for the audience as it "is capable of haunting its audience's dreams while simultaneously bringing them a sense of political truth and social understanding" (263). Blasted is one of her plays that exemplify brutality, inhumanity, and insolence. The protagonist lan seduces and attempts to rape Cate, the hotel Cate leaves is blown up by a bomb and a soldier finds lan to rape him. Then sucks out his eyes and eats them, which is followed by the soldier's suicide. The soldier says, "He ate her eyes. / Poor bastard. / Poor love. / Poor fucking bastard" as soon as he gets done with lan (Blasted 48). Even though it is quite understandable that the audience is overwhelmed with the rape, cannibalism, death and suicide scenes; the key point that Kane aims to reach with these scenes is much more humane. Her object is to emphasize the globally concerning issues such as human rights and genocide in Bosnia, using shocking images. As the play reflects the relation between the oppressor and the oppressed, namely lan and Cate and the soldier, the social satire begins to make itself apparent. In addition, the painful acts in each scene, from the explosion to the painful anal sex, provide a critical reference to the world history which has witnessed numerous genocides, wars, and destructions. Therefore, the play is not only a portrayal of the contemporary world but also "an experience of "dehumanization and disconnection'" (Eckersall, Grehan, and Scheer 168). The disturbing and shocking imageries are used in combination with dehumanization as a way of questioning and criticizing the moral issues and violation of human rights in the theatre of cruelty and In- 
Yer-Face theatre and excelled in postmodern theatre. Kane's theatre involves the social concerns in a global context, exposing dehumanization with sex-centred and violencecentred plots in her plays. Through exposure of vulgar language, sexual assault, cannibalism, and suicide, the playwright reveals the undeniably wicked side of humans.

Sarah Kane is seen as one of the most important representative playwrights of InYer-Face theatre. Oxford English Dictionary defines the term 'In-Your-Face' as "blatantly aggressive or provocative, impossible to ignore or avoid." Kane's plays offer extreme examples of violence, exploitation, frustration, and dehumanization and In-YerFace theatre makes it impossible for the audience to ignore or avoid the performance on stage but become a part of it. Sarah Kane's plays also comprise different themes by using violence as the main force. In Blasted and Phaedra's Love, violence is the major component of the events, characters and their traumas. However, in Crave, which is the fourth play of Kane, the situation is different. The script contains less violence, yet, dehumanization is prevalent. Instead of using violence as a main theme and making the characters as animal-like figures, she completely erases the identity of the characters in Crave. There is very limited information about the characters, which only includes their nation. In fact, there is no exact information about their gender and names. While hiding their gender and names, Kane illustrates very traumatic acts in the play such as rape and pedophilia. Even though violence is not the main theme, the play is still too provocative for the audience to overlook manifestations.

Phaedra's Love is based on a Greek tragedy and violence takes place on stage. The cruelty of human beings is one of the main topics of the play. Kane makes the audience question the essence of humanity and the unexpectedly high propensity for violence. The play starts with Phaedra's unrequited love for Hippolytus, her stepson. Although Phaedra is warned against the vanity of her affair and possible destructive consequences of the relationship, she turns a blind eye to all warnings. At the end of the play, the audience witnesses the incestuous relationships between Phaedra's family members. However, the most barbarous scene is presented after Phaedra's suicide. After learning the incest relationship between her husband, daughter, and stepson, Phaedra commits suicide and blames Hippolytus. At the end of the play, Strophe and Hippolytus are brutally killed:

Theseus pulls Strophe away from Woman 2 who she is attacking. He rapes her. 
The crowd watches and cheer.

When Theseus has finished he cuts her throat.

She dies.

Man 1 pulls down Hippolytus' trousers,

Woman 2 cuts off his genitals.

They are thrown onto the fire. The children cheer.

A child pulls them out of the fire and throws them at another child, who screams and runs away.

Much laughter...

He [Theseus] cuts Hippolytus from groin to chest. (Phaedra's Love 95-96)

Kane uses the "acts of violence and sexuality to force the audience into recognizing their own complicity in the violence of the contemporary world, even if it is simply through their complicity as passive spectators" (Cole 67). The act of violence is essential to recognize the dehumanizing actions in the world. As a female British playwright, Sarah Kane employs the elements of postmodern theatre which involves several innovative theatrical modes such as In-Yer-Face and theatre of cruelty/violence that comprises subversive themes and concepts. Sarah Kane is known for reflecting controversial topics in her plays and producing them boldly on stage. This paper will offer a reading of Kane's Blasted, Phaedra's Love, Crave, and 4.48 Psychosis in terms of the way they embrace dehumanization and alienation, reinforcing the use of the elements of postmodern theatre.

\section{Postmodern Theatre and its Attributes}

The term "postmodernism" emerged after the Second World War. It challenges traditional structures and ideas of modernism. Postmodernism may not be considered as a reaction to modernism, but it puts forward what is not presented by modernism. The interrogation of beliefs and values connected with modernism ensues in postmodernism. Postmodernism is the transitional period that the viewpoints of modernism are being entreated into an enigma. It is a movement characterized by broad scepticism, subjectivism, and relativism in the late twentieth century. It can be defined as a general mistrust of reason and an intense sensitivity to the position of ideology in 
claiming and retaining economic and political control. "Central to postmodernism is the recognition that 'reality' is itself a construction, a representation. Human subjectivity makes sense of its world, imposes upon it a meaningful design using those conceptual tools culture provides" (Counsell 207). Postmodern art and literature show the self as being detached from society's traditions. The result of its influence on drama is seen as a change that does not try to build the vision of reality the way it is perceived in the past. Postmodern drama aims to create an abstract, distorted world and it holds a specific type of power. The audience acknowledges that the created world cannot be described in reality.

With the effects of postmodernism in theatre, performance becomes the focus and the concentration has moved from sense to interpretation and the effect performance produces. The fusion of media and related technologies, and the scepticism of metanarratives lead to the challenge of the substantive link between dramatic devices and remove the strategy that treats theatrical instruments such as acting, music, stage props, and costume as elements that only clarify the text. Technology and media tools replace all traditional theatrical objects.

Postmodernist drama gets rid of the strict limitations of modernism regarding style and ideology. Postmodern plays have no rigid structure, storyline, and style. Moreover, minimalism, distortion, breaking the fourth wall, and the overabundance of the theatrical signs become the elements of postmodern drama. Indeed, postmodern drama is a reaction and a critique of modern drama. The term "postmodern" questions what is not questioned before in modern but "still exists with some kind of reference to it," in fact it is still a part of "modern" (Lehmann 27). "Despite the fact that Lehmann opts for the term 'postdramatic' instead of 'postmodern' to describe the new theatre, his theory of postdramatic theatre is of course resonating with many aspects of postmodernist thinking" (Karen Jürs-Munby quoted in Lehmann 13). Postmodern drama does not attempt to create an illusion for the reality but to create a deformed world on stage to reflect the isolated, postmodern individual. It explores human beings in the postmodern world. "The attempt to stimulate appearance was fundamentally flawed, and the early twentieth century was marked by a series of artistic movements which sought to figure out the world in new, non-realistic ways" (Counsell 207). New theatre emerges and creates a continuing association and exchange between actors and audience. The new theatre that encompasses postmodern drama, is the new, modern way of theatrical 
expression which is no longer dramatic. The dramatic theatre has embraced the use of the subjective "I" and presented an outlook of life in a setting familiar to the audience. However, postmodern theatre as Lehmann considers it a subfield within postdramatic theatre rejects the simple, logical, and causal sense of life that the traditional dramatic forms portray. Postmodern theatre in its core disputes that the world is not as plain as the dramatic theatre presents and shows that theatre should exhibit the challenges and the multiple reasonings of life. Life is not coherent, compassionate, and deferential; it is chaotic, cruel, and ruthless like the postmodern theatre.

Postmodernism in drama flourished in late twentieth century and it is against the ideas, techniques, and strategies of modernism. The rooted ideas in modernism have changed due to the incidents during the twentieth century. Through a scrutiny and comparison between modernism and postmodernism in drama, it is evident that modernist drama focuses more on the structure of the play. Postmodernist drama examines the plays in terms of content rather than structure and it deals with a range of topics from poverty, inequality, violence, rape, and dehumanization to alienation. With postmodernism in drama, the relationship between the audience and players has shifted dramatically. Postmodern drama creates an environment for the audience to realize that they are part of the performance. Significantly, postmodernism in drama leads to developments and increase in new types of drama, practicing new methods that have not been used before, involving technological developments and the emergence of film industry. Ursula Martinez's show called O.A.P directed by Martin Whitelaw, and the reaction of the audience when Martinez appears on the stage disguised as an old woman and asks if anybody would like to kiss her are illustrative of the stylistic traits in postmodern performances. Martinez evokes the reaction and the question that indicates the audience's anxieties and the paradoxes they face with, through her question. "We were left to decide whether it was just the distance to the performer on stage or the image of old people as non-sexual beings that prevented us from volunteering to kiss her" (Lehmann 5). The impact of media on postmodern performances uncovers the capacity of technologies and in what way they are related to our lives. "The impact of media manifests itself not in the use of high-tech 'multimedia' on stage, however, but sometimes also in its very opposite: theatre on a bare stage with minimalist, pared down aesthetics, which nevertheless can only be understood by being related to life in a "mediatized' society" (10). The impact of media mentioned above emphasizes that postmodern performances are an inseparable part and also a reflection of society. As society evolves, a need arises about a change in the elements, subjects, and role of 
audience in postmodern drama which eventually and permanently relates back to the impact of media.

Innovations in drama involve change in the audience's role from being passive receivers to integrating in the performance. Unfinished sentences emerge as an invitation to fill in the blanks in the dialogues; the narrative is fragmented, and not necessarily complete. According to Radu Teampău, metanarrative in postmodern theatre has an important effect on the structures of plays: "The postmodern emphasis on metanarrative had as a secondary, deliberate or not, effect the apparent pulverisation of narrative itself and not just of narrative structures" (191). There is not necessarily a coherent plot in postmodern plays and conclusions are not required. The aversion of the truth could be seen as the reason for the disinterest in conclusions.

Postmodern drama does not simply eliminate the traditional elements of drama, but also changes and develops them to evoke different emotions and ideas that do not conform to the understanding and the acceptance of the conventional drama. Postmodern drama thrives in its questioning. According to Kerstin Schmidt, postmodern drama entertains the conventions of the mode of modernism as "a communal ritual" (11) while also undermining and excelling modernist values in the process. This undermining might occur in many ways such as engaging in a metadramatic retelling of another work of drama that concerns itself with the play rather than the text of the play or engaging in out-of-text and unexpected changes in a performance. These examples of postmodernism in drama find their roots in several concepts from postmodern discussions playing out in drama. "Self-referentiality" (16) is one such concept, which is the text being aware of its fictitiousness. Postmodern drama presents itself in a manner that questions itself while also allowing the audience to question the meaning, or the lack of meaning.

In postmodern theatre, performance is the main subject to be dealt with and the text will only be an element mentioned. Theatre always deals with "ethical, moral, political and legal questions" (Lehmann 18). Enthusiastic, admirable, and intriguing state of the theatre has been coalesced with new experiences and categories such as Avant-garde, In-Yer-Face, and Fringe Theatre. In all these genres, expression and depiction of the written text constitute the staging and making the audience active participants and receivers of the performance. Even in times when music and dance are the most prominent and effective elements, audience has always been decisive. Illusions 
have always been the cornerstone of theatre, because creating a whole new world of fiction and fitting it into a scene is nothing more than an illusion. The audience is subjected to "the theatrical impact of the shocking new plays which exploded onto the London theatre scene in the 1990s" (Sierz 20).

\section{Subhuman Characters in Blasted, Phaedra's Love, Crave, and 4.48 Psychosis}

In Blasted (1995), Phaedra's Love (1996), Crave (1998) and 4.48 Psychosis (1999), Kane demonstrates the repulsiveness of human interaction. Four plays under discussion assume the theme of oppression that puts pressure onto the individuals drawing them to reflect a portion of themselves that they do not intend to show. Pressuring impact of the oppression forces individuals to react inherently primitive and hence personal. Kane uses the theme of violence as an instrument to explore the nature of the oppressed, and violence carries importance in Blasted, Phaedra's Love, Crave, and 4.48 Psychosis. Furthermore, violence induces the confusion of humanity to animality unveiling the concept of dehumanization in the plays. Sarah Kane's selected plays Blasted, Phaedra's Love, Crave and 4.48 Psychosis present major traumatic events which dehumanize the characters. The audience witness anger, frustration, and depression as the side effect of these traumas, yet lack of information about the characters turn them into obscure individuals and therefore their traumas lose their disparaging effect.

In postmodern theatre, the text of a play moves away from its traditional aim and structure of being in the center and becomes a conducive part of the play. This enables more flexibility in the plays and creates an opportunity to bring performances close to reality. The problem of dehumanization appears on stage with the questioning of reality and human existence. Sarah Kane reflects the meaninglessness of life, and questions human existence through the characters in Blasted, Crave, 4.48 Psychosis, and Phaedra's Love. The characters' purposelessness in life and suffering dehumanizes them. Kane reflects this by not specifying the characters and stage directions. Lack of stage directions reflects the complicated condition of the characters' mind, and the stage becomes the mind of the characters, in a sense. As Marvin Carlson declares, "the same space is shared by audience and performance and the focus is variable and flexible. All production elements speak for themselves, and none is necessarily subordinated to the rest. This includes the text, which has no necessary primacy and in fact may disappear altogether" (479). One of the most important features common to all the above-mentioned plays is the use of language. Sarah Kane uses language as a tool to present the psychology of the characters. She develops the themes of violence, death, 
lack of love and affection, in relation to dehumanization with the use of language. "While images were central to her previous plays, these final pieces contain the images within the language of the plays, and she does this through the creation of a distinctly poetic style. Both plays Crave and 4.48 Psychosis] are performance texts, with no stage directions, and in the case of Psychosis, no speaker designations" (Urban 43). The process of meaning making for the audience depends on the use of language, as the themes are transmitted in the dialogues.

C. I'm evil, I'm damaged, and no one can save me.

A. Death is an option.

B. I disgust myself.

C. Depression's inadequate. A full scale emotional collapse is the minimum required to justify letting everyone down. (Crave 3 )

In Crave, most of the time, it is hard to understand whether characters are in a dialogue with each other or just elaborating on their psychologies in a verbal discourse.

In Kane's debut play Blasted, the interaction between Cate and lan showcases the repressive structure of the oppressed and the oppressor. lan's manipulative approach to Cate is an indication of his primitive need to assert dominance. In the first act of the play, Ian attempts to seduce Cate, gets undressed and says, "put your mouth on me" (Blasted 7), however, Cate's reaction humiliates Ian. Confronting such a humiliation, Ian feels exposed and runs away to recover. "He gathers his clothes and goes to the bathroom where he dresses" (7). The bathroom signifies the safe place where he cannot be seen by anyone else. This resonates behaviours of an animal seeking shelter after facing a threat. lan's attempt to seek shelter suggests that he failed to assert his power over Cate and hence he lost his dominance over her. After he dresses, he tries to acquire the dominance he lost by posing a question that can shake Cate's self-esteem. "You got a job yet?" (7) lan continues his pressure on this topic and draws the conversation to Cate's incompetence and her lack of intelligence. Due to the pressure asserted on her, Cate faints, and consequently lan acquires his dominant place in the interaction. Ian's desperate need for power is displayed in this scene and his primitive instincts are exposed. More importantly, this scene portrays lan's animal-like instincts to run away, recover and attack again and again, which alludes to the concept of dehumanization where Ian is depicted to be a predator. As the play progresses, Kane reflects the 
competitive aspect of human nature through lan's characterization.

lan's attempt to suppress Cate and force her to satisfy him through his manipulative manners displays one of the most prominent aspects of patriarchy. In a society that is shaped by patriarchy, the oppressor uses his power to subject the oppressed into a role that benefits the oppressor. Even though lan's oppressive manners fit the stereotypical patriarchal oppression, in the following scenes it becomes evident that lan's existentialist thoughts cause him to Crave affection and power, and hence make him violent against mostly himself. lan's words concerning life and living shed a light on his standpoint in violence and humanity. Ian states that he cannot stand "Death, Not being" (Blasted 10). Nevertheless, later it is revealed that he is not scared of the idea of dying. When the Soldier states that he will kill lan, he simply answers "fine" (46) as an indication of his indifferent standpoint. Even though lan's answers to the phenomenon of death draws a conflicting portrait, "Not being" is a different take on existence. Indeed, lan does not resent the idea of dying, he rather resents the idea of death and the aftermath of death where the human becomes a corpse, an inanimate object. lan's bitterness about death reveals one of the fears of humankind that is the state of being insignificant or having no value. Dying carries a value within itself, it represents the looping process of life and death. Kane, through lan's existentialist crisis over death, poses questions that are hard to digest answers. While this accomplishes Kane's aim to depict the unspoken truths of life, it also alludes to the concept of dehumanization that centralises its core to the dilemma of humanity and animality.

Blasted reveals the impact of violence on oppression and how violence is interconnected with primitiveness. Sarah Kane draws the readers' attention to the overwhelming pressure imposed on human beings. Kane's depiction of human interaction puts emphasis on the power dynamic between individuals and how this power dynamic reveals the primitive instincts within them. lan's most violent self and dehumanized self becomes most prominent when he faces intense emotions. He feels scared when Cate faints and consequently, he reveals his fear of death. The play makes it evident that primitiveness and violence are interconnected, and they both allude to the concept of dehumanization that Kane utilises to show the importance of oppression in human interactions. Kane offers the audience "a world of catastrophe" (Urban 43). Sarah Kane relates that, "there isn't anything you cannot represent on stage. If you are saying that you cannot represent something, you are saying you cannot talk about it, you are denying its existence. My responsibility is to the truth, however difficult that truth happens to be" (Urban 45). In other words, Sarah Kane argues that the truth is brutal 
and dehumanizing; however, it is her intention as a playwright to reveal the truth to the audience in her plays. She is against ignoring the violence and dehumanizing outcomes of wars. At the beginning of the play, Ian rapes Cate. Then a soldier comes to the hotel room and brings more violence to the play and brutally rapes lan:

(He kisses lan very tenderly on the lips.

They stare at each other)

You smell like her. Same cigarettes.

He guts up and turns lan over one hand.

He holds the revolver to lan's head with the other.

He pulls down lan's trouser, undoes his own and rapes him-eyes

closed and smelling lan's hair.

The Soldier is crying his heart out.

lan's face registers pain but he is silent. (Blasted 47)

An unpleasant scene that creates disgust and annoying feelings follows with more violence and merciless scenes. The soldier sucks lan's eyes and eats them. Furthermore, Ian eats a baby after its death. Kane's main intention is to characterize the truth that nobody dares to acknowledge. According to her, the existence of violence should not be avoided. By using elements not very frequently used before, Kane provokes the audience to come out from their safe zone to question the violence in the world.

Blasted is an example of In-Yer-Face theatre that challenges the audience with unpleasant imagery and filthy language of the unbearable truth. Kane's attitude toward experimental theatre involves changing the spectator's passive role to active participation by engaging them in performance. "They may experience [the patterns of action] isomorphically as a kind of psychic echo. Their detailed empathetic response will be determined by associated factors, the 'ground,' and the pure 'experience' itself will be further conditioned by an inescapable element of meaning" (Carlson 486). Blasted examines violent nature and society's understanding of war by using three individuals who perform violent acts to each other. Throughout the play, the audience is exposed to vulgar language, sexual assault, cannibalism, and suicide; therefore, the grotesque imagery shakes the audience's consciousness to stand up against the patriarchal, racist, 
and bigot politics. In Blasted, Kane indicates violence in modern society by suggesting that violence's essence is unvarying whether it is in the domestic or public sphere.

In Blasted, violence in domestic sphere is represented by lan and Cate's relationship. While Ian humiliates Cate mentally and physically, Cate tries to look after him by telling him to stop smoking and drinking and providing him food. lan is suffering from cancer, and as he is not ready to accept the fact that he is dying, he behaves selfdestructively and aggressively toward everything, including Cate. Ian insults Cate by using a filthy language for her fashion sense, and her relationship with her mother and disabled brother. lan's sexist and racist comments dehumanize his character as he objectifies people. Cate exhibits a more humane attitude during this conversation by telling him to stop calling people names, yet her naive manner only signifies inferiority in his eyes. Ian hates feeling victimised and ill; therefore, he rapes Cate to reinforce his power and superiority over her. lan's attempt to rape objectifies Cate, and by sexually assaulting her, lan is dehumanizing both himself and Cate since it now turned them into the perpetrator and the victim, sharing the same roles. The rape scene uncovers the domestic violence and shows the audience that danger is never far away. Elaine Aston declares, "Kane aims to make us see and feel the effects of violence not as a world outside of ourselves, othered and neutralised, but as inside our lives, value systems, choices and behaviours" (578). The mental and physical violence in the rape scene flings violence's essence up in the spectator's face in a rather grotesque way, yet brutal stage imagery is essential to In-Yer-Face theatre. In-Yer-Face theatre raises consciousness with shocking and brutal scenes.

Violence in public sphere is presented in the subplot with lan and the Soldier's encounter. The Soldier's attempt to rape changes lan's role of the perpetrator to the victim and challenges gender roles about sexual assault, therefore, the Soldier's rape represents the connection between violence in the domestic sphere and the public sphere. lan's superiority lasts a short time, and he turns back to being powerless, therefore, lan's new role as a victim illustrates patriarchal society's effect on the weak and the helpless. Cate comes back with a baby after this incident, yet the infant dies, and lan eats its flesh. Cannibalism on the stage is associated with the theatre of cruelty and the grotesque imagery used for disturbing the audience and shaking them with the unbearable truth as all the intolerable activities performed by dehumanized characters reflects society's position against reality. The Soldier's sexual assault shows war's dehumanizing impact on everyone since it is implemented by a war hero in a patriotic perspective. Furthermore, the Soldier's attempt to rip lan's eyes out represents media's 
blindness to the Bosnian war since lan is a journalist. In Blasted, lan says, "I write... stories. That's all. Stories. This isn't a story anyone wants to hear" (Kane 47). The metaphorical blindness becomes more striking when lan objects the Soldier's request about the news by suggesting that nobody wants to hear their story. Society's indifference toward global issues is displayed by ripping lan's eyes out in the play, and thus, it is intended to make the audience feel guilty and dehumanized.

Blasted points out the issue of violence in the world and people's apathy toward the incident. While lan's abusive language and his attempt to rape Cate reveals violence of an individual, the Soldier's sexual assault of lan is a criticism of organized violence that sets light to the subject of raping as a war crime. The metaphor of ripping eyes out shows media and society's blindness to social and political matters, and the infant's death symbolises Kane's hope for the future. Kane also refuses gender roles in the subject of rape and points out that there is only the perpetrator and the victim. The disturbing imagery and language throughout the play is a part of In-Yer-Face theatre and it aims to affect the audience's point of view and shake them up. "This kind of assault on the audience is experientially purposeful in its attempt to break the inability to feel a responsibility for the sufferings of others" (Aston 583). Alluding to the play's title, the audience witnesses both a sexual explosion and an explosion in a real war scene, as well as a ruthless battle between not only men and women, but also between men and men, and as a result, the defeat of human beings. The rape scene turns into a war scene and the surreal change enables the audience to feel frustration as a result of the exasperated experience presented on stage. The critical awareness, which is caused by dehumanization, proves to the spectator that the play reflects dehumanization via both the rupture and violence. It is very critical indeed to present reality on stage, as it creates unpleasant feelings that the audience never enjoys watching but the playwright boldly conveys.

In Crave, Kane introduces the audience with four voices without specifying their sexes, ages or ethnicity. They do not communicate with each other most of the time, yet the fragmented voices combine and create one whole body. Kane's writing style persists in her last play 4.48 Psychosis, in which an unnamed woman who has psychotic condition struggles and questions the meaning of her existence. Kane uses the aspects of postmodern theatre in Crave and 4.48 Psychosis, and reflects the dehumanized individuals in the modern world through the themes of alienation and frustration. 
Alienation appears as a theme in the plays as she approaches the minds of the individuals who are disconnected from the outside world and even from their own body. As the characters are both alienated from the outside world and themselves, they are dehumanized. They lack what makes them human; body-soul wholeness, and interaction with others. In Crave and 4.48 Psychosis, the audience observes idle "minds" that lost their purpose in life. In Crave, Kane looks "to a wider concept of performance" than her previous works, which focuses on an "intense connection with the spectator" (Singer 141). The spectator becomes connected with those minds and also realizes the truth in between the speeches. The characters, A, B, C and M, are dehumanized voices in Crave. In one of the scenes, B says that "If I lose my voice I'm fucked" (Crave 43). Characters' alienation from the outside world is observable in the speeches of M, "I mustn't get attached" (15) and C, "I'm evil, I'm damaged, and no one can save me" (21). Their traumas and pains of love, rape and incest are the core matter in their speeches. Alienation that develops to a state of self-alienation appears in Kane's 4.48 Psychosis with a single protagonist this time. In 4.48 Psychosis, dehumanization begins by not giving a name to the character who constantly suffers from the disharmonious state of her body and soul invariably disconnected. She is reflected as a voice like the characters in Crave, "a disembodied voice speaks. The question of 'who' is speaking is only partially answered" (Kaplan 122). The disconnectedness of the character's body and soul leads her to purposelessness. Gradually, her existentialist sufferings create discomfort in the audience as they also start to question reality with her. She is alienated from herself and says, "It is myself I have never met" (4.48 Psychosis 43). Her speech appears as a monologue in the play which expresses the themes such as "disruption of communication and the isolation of the individual" (Lehmann 128). The failure of communication mostly appears in dialogues "while a monologue as a speech that has the audience as its addressee intensifies communication" (128). The character's pain and struggles that push her to alienation are delivered more powerfully in 4.48 Psychosis than Crave's fragmented style.

The manifestation of frustration in Kane's plays appears as an outcome of alienation and dehumanization of the characters. The characters are captured and isolated, especially in their mind, that they cannot do anything to free themselves. In one of the productions of Crave in Hampshire College, they experimented with a physical representation of the captivity of the characters. Their "design consisted of a humansized cage, which contained the actors. The cage imprisoned the actors, and also aggressively contained the audience in uncomfortable proximity to the stage, up against 
the cage itself" (Kaplan 123). This postmodern representation of captivity and isolation end up as frustration as the characters do not have the freedom to get out. In the play, the characters try to become whole with the words to escape from this captivity: B. Let / C. Me / M. Go. (Crave 37) They become frustrated as seen in the line C utters, "I'm much fucking angrier than you think" (37), and find themselves in an uncontrollable state as B says, "it's out of control" (33). The manifestation of frustration also appears with Kane's use of repetition in both Crave and 4.48 Psychosis. In Crave, C repeats "What have they done to me?" (39) several times, which is both a realization of and a reaction to the situation. Likewise, in 4.48 Psychosis, the woman repeats the same patterns, "How do I stop?" (24), which reflects her despair and anger. Lehmann states that "the reality of the voice itself is thematized. It is arranged and made rhythmic according to formal musical or architectonic patterns; through repetition...separated from the figures as disembodied and misplaced voices" (149). The repetition reflects the separation of the voices from their source and dehumanizes the characters. In 4.48 Psychosis, "a conversation between patient and therapist becomes clear" sometimes and at other times, we witness "the conflicted, racing, fastidious thoughts of a suicidal mind" (Singer 160). The character's frustration is visible in both the conversations and her monologues laden with repetitions.

Consequently, dehumanization in Sarah Kane's Crave and 4.48 Psychosis appears as a central theme that continues throughout the plays. It is supported with the aspects of postmodern theatre, beginning with alienation that later leads to frustration of the characters. The characters' disconnectedness from life and their body leads them to a never-ending cycle of existentialist suffering and pain. Through repetition and silence, Kane creates distorted voices that are not unified. She questions reality by creating a metaphorical mirror on stage in which characters reflect the spectators. Kane's plays are the pinnacle of suicidal tendencies and depression as requisites of the postmodern world. A bond is built between the depression and melancholy that the characters and the audience experience. The provocative and exhilarating plays of Sarah Kane mirror the harsh realities of human life in a shocking way. Mostly dealing with the disturbing aspects of life, such as violence and cruelty, Kane makes the audience visualize the unspoken aspects of the evil in human nature.

When the recurrent themes of the plays such as suicide, murder, mental disorder, drug addiction, pedophilia and rape are taken into consideration, they are challenging 
for the actors and the audience, but Kane makes the topic of brutality casual with its repetition in the play. In Rape and Rape Mythology in the Plays of Sarah Kane, Ian Ward explicates how many sociologists and scholars see the rape as the perfect act of the male sexuality in patriarchal culture and the ultimate metaphor for domination and violence (226). However, in Crave, the act of rape is not about social behaviours of women and men and there is no political criticism as well. Ian Ward states that "Kane had no interest in subscribing to any particular feminist position on rape" (229). The hidden identities of the characters can be related to this argument since Kane does not want to highlight any topic but isolation and dehumanization. That's why she makes the characters $\mathrm{C}, \mathrm{B}, \mathrm{M}$ and $\mathrm{A}$ abstract figures, and both their feelings and traumas are not related to their gender:

M: You think I'm going to rape you?

C: Yes.

A: No.

B: Yes.

M: No.

A: Yes.

B: Yes.

C: Yes.

$\mathrm{M}$ : Is that possible?

C: I see no good in anyone anymore." (Crave 11)

Their conversation comprises of depression and sadness, and the only background information provided about their personal identity is their nationality. The remorse that they feel because of the dehumanization can be observed in their dialogues no matter where they belong to and where they come from. While referring to some of the dehumanization crimes, their dialogue deprives of the features of an eloquent exchange and turns into a heart-searching. In "An Ethics of Catastrophe: The Theatre of Sarah Kane," Ken Urban states,

While the narrative suggests the pain of individuals, the play has a distinctly international consciousness; B's use of Serbo-Croatian, Spanish, and German takes the personal and places it in a global context. The speakers's stories, as a result, become almost superfluous to the concatenation of 
images. Yet, the roles of the speakers have the power to complicate the language's ornate images again placing the viewer in a space of moral uncertainty. (43)

Since Kane aims to illustrate the isolation and futility of life, she is implying that immorality is everywhere and acts of violence, rape, pedophilia are not related to any social background including where people were born or live. In the play, people from different places narrate stories but their nationality does not add anything to the stories. All embracing elements in Kane's plays point to the denial of humanity in others. The audience cannot find common or different values which will separate people according to their moral sense.

In the play, the theme of dehumanization and isolation can also be explained in terms of symbols and colours. In the play, there is an emphasis on whiteness and lightness. In White on White and Black': The Terror of Whiteness in Sarah Kane's Crave, Meg Peters states, "lightness and whiteness are potentially hopeful concepts in a colourful, unknowable project and the silence of the characters allows more light to sleep through the cracks of their utterances. At the same time, we might also view this lightness and whiteness as forms of terror, if we view it through hooks' framing" (109). White colour and whiteness illustrate isolation and terror but characters have complicated relationships with these elements. For instance, some characters want to be black, yet others state they will not settle for a life in the dark and the audience observes repetition of white and light throughout the play. References to whiteness and lightness illustrate the confusion of the characters. Repetition of white and black makes these terms less meaningful as well and the text eventually tells that there is a vague line between moral and immoral.

Like in her other plays, Sarah Kane claims the losses of society and the individual are not different from each other. The process of depriving someone from positive human qualities can be valid for both an individual and a larger group. The dehumanizing consequences of sexual violence are exposed as different kinds of traumas. Characters of the play are isolated and unstable. Even though there is no actual violence in Crave, the audience sees major struggles of the characters such as frustration, shame, mental disorders, suicidal thoughts, and even the denial of depression and madness. Furthermore, by not giving the characters an essential form as humans such as avoiding giving them names and presenting an everlasting fluidity about their gender, Kane 
clearly draws a realistic picture of the consequences of immoral actions and how both victims and abusers lose their sense of humanity as discussed earlier in the analysis of Blasted.

Like Blasted, in Phaedra's Love, Sarah Kane expresses the theme of violence through the phrase "I love you" (15). In Blasted, the expression of this phrase in lan's speech is followed by his raping of Cate. Later in the play, after the Soldier rapes Ian, love is invoked by the Soldier in a pitying manner as seen in his last words. Similarly, in Phaedra's Love, Phaedra states the phrase "I love you" (77) to Hippolytus, which is followed by her suicide and accusation of rape towards Hippolytus. Both plays alter the expected into the unexpected, utilize the phrase as an indication that violence and conflict will follow it, unlike making use of the traditional associations of bliss and happiness with the phrase. In Blasted, Cate grows uncomfortable through lan's suggestions, and she stammers, making it clear that she is not receptive to him at that moment. This is followed by lan's statement of the phrase in question in a way that is supposed to excuse him from his own behaviour: "Sorry. Pressure, pressure. I love you, that's all" (Blasted 15). Prior to this statement, lan constantly belittles Cate, claiming that she is unintelligent, making fun of her clothing by comparing her to a lesbian in a way that is supposed to be derogatory towards lesbians (7). Ian is not sincere in his love expression which is supposed to be an excuse for his abuse of Cate to make her more receptive to him. After a flurry of racist insults to a man who Cate likes, lan says, "Cate, love. I'm trying to look after you. Stop getting hurt" (16). After his dehumanization of a black man because of his own jealousy, lan claims that he is trying to be protective of Cate, saying, "I love you" (16) again. lan passionately avoids forming empathy with other people because of their ethnicity, while claiming to be compassionate towards Cate. This combination of hate and love is ingrained in lan as he later states the following words about his ex-wife: "I loved Stella till she became a witch and fucked off with a dyke, and I love you, though you've got the potential" (17). Likewise, lan blames his own failings as an individual to be a good person on his former spouse, prematurely blaming Cate for having the potential to do the same. lan's statement of the phrase continues as Cate repeatedly rejects him, which ends in his raping of Cate. This is followed by lan himself getting raped by the Soldier. Ward compares lan's rape with that of Cate in the following excerpt: "It is not as such a domestic environment. But it is an environment in which a species of rape familiar in domestic environments can take place" (230). The luxurious hotel room turns into a scene of a battlefield, and the rape that occurs at home is followed by a rape that occurs in a place at war, by a soldier carrying a rifle in a 
battlefield. The rape of Cate is preceded by the pretence that there is love, an illusion which veils the fact that he is violently using Cate's body. This is compared with lan's own rape which is without this pretence. In his last words before committing suicide, the Soldier pities Ian: "He ate her eyes / Poor bastard / Poor love" (Blasted 48). Similar with lan's proclamations of love, the Soldier uses the word "love," albeit in a more pitiful manner than an excusing one. In both instances, love is taken out of its original connotations and placed into relationships that are defined by violence and abuse.

Love has a similar position in Phaedra's Love. Insinuating that her mother has feelings for Hippolytus, Strophe states the following:

Strophe: You're in love with him.

Phaedra: (laughs hysterically) What are you talking about?

Strophe: Obsessed. (Phaedra's Love 65)

Strophe equates love with obsession, mystifying the meaning of love. Similar with the use of love in a manner that justifies violent and abusive behaviour in Blasted, it is used interchangeably with obsession in Phaedra's Love. Phaedra's obsession with Hippolytus manifests itself in her insistence of having a sexual encounter with him, which occurs with the reluctant consent of Hippolytus. Her obsession contrasts with Hippolytus' indifference:

Phaedra: I did it because I'm in love with you.

Hippolytus: Don't be, I don't like it. (77)

As a result of Phaedra's obsession not being satisfied by Hippolytus, she commits suicide and accuses him of raping her, causing the death of everyone in the Royal family. Done in the name of love, it shows the way the term is used without echoing its wellknown connotations. The portrayal of Hippolytus, like the concept of love, is quite fluid. "That vertiginous sense we experience, fluctuating between disgust and tenderness for Hippolytus, is a trademark of Kane's theatrical universe, one that the reading conveyed palpably" (Urban 42). Hippolytus is in contrast with Phaedra in his lack of concern, which leads to the allowing of his own execution. Blasted makes use of symbols and change in environment, as well as a general unravelling of rational progression throughout the play, becoming more absurd as the play nears its end. Similarly, Phaedra's Love is also quite absurd in its depiction of the Royal family, which could evoke mixed feelings in the 
audience based on their own opinion with regards to the Royal family in the United Kingdom. The absurd and "the experiential became a byword for 'In-Yer-Face' theatre" (Aston 580). In this sense, Phaedra's Love challenges the institution of monarchy while Blasted subtly invites the audience to question the difference between the metropolis and the periphery, melding them in the same setting with two instances of violence and abuse, "the way it "blasts' postemotionalism" (582).

\section{Conclusion}

Sarah Kane's Blasted, Phaedra's Love, Crave, and 4.48 Psychosis are examples of postmodern theatre with their unique structures, shaped according to the essentials of the postmodernist theatre. Not the text, but the performance is at the core of these plays. In addition to their similar structures, they also have common themes, such as dehumanization, violation, exploitation, pain, depression, and the lack of love. Kane displays and highlights these themes in tandem with the features of postmodern dramatic structure. Postmodernism in performance art provides a new perspective and role to the audience, focusing on the relationship between the audience and performance in which the audience becomes a participant. As Lehmann indicates, "antiquity, pain, violence, death" have been common to theatre (165). In Sarah Kane's plays, pain, violence, and death indicate the dehumanized world of the twentieth and twenty first centuries. Kane probes the audience into perceiving the violent world around them, encouraging the audience to reach their own individual understanding. Kane's representative plays of postmodern theatre raise questions rather than attempting to offer answers. She employs the elements of violence and dehumanization to capture the audience's attention. Dehumanization is a crime against humanity, it is the process of ignoring morality and the adverse outcomes of it are generally psychological, examples of which can be observed via the characters in Kane's capturing plays which aim at shocking the audience. The theme of dehumanization is employed in alliance with the aspects of postmodern theatre. In Kane's dramas, nothingness, futility, alienation, frustration of the characters depicted in a substantially bold manner on page and on stage. Their disconnectedness from life leads them to an iteration of existentialist suffering and pain. Through repetition and silences in her plays, Kane creates inaccurate and inarticulate voices that are not coalesced.

\section{WORKS CITED}

Aston, Elaine. "Feeling the Loss of Feminism: Sarah Kane's 'Blasted' and an Experiential Genealogy of Contemporary Women's Playwriting." Theatre Journal. 62.4 
(2010): 575-591. Web. 10 May 2021.

Carlson, Marvin. Theories of the Theatre: A Historical and Critical Survey, from the Greeks to the Present. London: Cornell UP, 1993.

Cole, Emma. "Paralinguistic Translation in Sarah Kane's Phaedra's Love." In Adapting Translation for Stage. Ed. by Geraldine Brodie and Emma Cole. London: Routledge, 2017.

Counsell, Colin. Signs of Performance: An Introduction to Twentieth-Century Theatre. London, NY: Routledge, 1996.

Eckersall, Peter, Helena Grehan, and Ed Sheer. "New Media Dramaturgy." In The Routledge Companion to Dramaturgy. Ed. by Magda Romanska. London: Routledge, 2014. "In-Yer-Face." The Oxford English Dictionary Online. Oxford UP, 2021.

Jordan, Eamonn and Weitz, Eric. The Palgrave Handbook of Contemporary Irish Theatre and Performance. E-book, Palgrave Macmillan, 2018.

Kane, Sarah. Blasted. London, Royal Court Theatre: Methuen Drama, 2011.

Kaplan, Ellen. "The Cage Is My Mind: Object and Image in Depicting Mental Illness on Stage." Studies in Theatre and Performance. 25.2 (2005): 115-28. Web. 12 May 2021.

Lehmann, Hans-Thies. Postdramatic Theatre. Translated by Karen Jürs-Munby, USA, Canada:Routledge, 2006.

Peters, Meg. "'White on White and Black': The Terror of Whiteness in Sarah Kane's Crave." TheComparatist. 4.2 (2018): 98-114. Web. 12 May 2021.

“Postmodernism." OED Online. Oxford University Press, 2020. Web. 10 May 2021.

Schmidt, Kerstin. The Theater of Transformation: Postmodernism in American Drama. NY: Rodopi, 2005.

Sierz, Aleks. In-Yer-Face Theatre: British Drama Today. UK: Faber, 2001.

Singer, Annabelle. "Don't Want to Be This: The Elusive Sarah Kane." TDR/The Drama Review.48.2 (2004): 139-71. Web. 10 May 2021.

Teampău, Radu. "Theatre Performance in Postmodernism." Theatrical Colloquia. 8.1 (2018): 187-205.Web. 10 May 2021.

Urban, Ken. "An Ethics of Catastrophe: The Theatre of Sarah Kane." PAJ: A Journal 
of Performance and Art. 23.3 (2001): 36-46.

Ward, Ian. "Rape and Rape Mythology in the Plays of Sarah Kane." Comparative Drama. 47.2 (2013): 225-248. Web. 10 May 2021. 